\title{
Prospects of the Russian-Mongolian interaction in the innovative sector of agriculture
}

\author{
Sergey Filin ${ }^{1, *}$, Aleksey Yakushev ${ }^{1}$, Maxat Berdikulov ${ }^{2}$, Vladimir Velikorossov ${ }^{1}$ and Aleksey \\ Chaikovsky ${ }^{1}$ \\ ${ }^{1}$ Plekhanov Russian University of Economics, Department of Management, 117997, Stremyanny \\ Lane, 36, Moscow, Russian Federation \\ ${ }^{2}$ SILKWAY International University, 160011, Tokayev Street, 27a, Shymkent, Kazakhstan
}

\begin{abstract}
The article raises an relevant topic - the direction of RussianMongolian interaction in the agricultural innovation sector. The purpose of the article is to offer recommendations on the implementation of a set of innovatively oriented measures in the field of agriculture in Mongolia using Russian technologies. The novelty of the article is the identifying trends in the development of innovative interaction of agricultural production in Russia and Mongolia based on Russian technologies. The analysis of changes in the level of innovation of Mongolia and the development of its agriculture is carried out, the main problems that inhibit development are identified. It is concluded that the mutual desire to increase the effectiveness of cooperation in science, innovation and education should provide a positive effect on the development of Mongolian agricultural production and industries that process agricultural raw materials, and accelerate the economic growth of agricultural production.
\end{abstract}

\section{Introduction}

Agriculture and raw materials industries in general are of particular importance to ensure the physiological needs of the population, and to provide primary resources for industry. Due to the direct use of land as an object of labor and natural chemical and biological processes in the production process, the influence of agriculture on the ecological balance of the biosphere is also significant. In a number of countries, including agricultural products, it produces a significant share of gross domestic product. The need for innovative development in the agricultural sector (AIC) is obvious both for any state and for each individual economic entity.

The territory of Mongolia and a number of Russian regions adjacent to the RussianMongolian border are part of the rapidly forming East Asian economic megaregion. Currently, the main driver of its formation is the intensive economic development of the People Republic of China provinces bordering Mongolia and Russia from the South [1]. The current slowdown and even possible retrograde movement of globalization processes in a high degree of probability will not affect the formation of this economic mega-region,

\footnotetext{
${ }^{*}$ Corresponding author: Filin.SA@rea.ru
} 
moreover, its formation may accelerate. In the described complex of integration processes in Russia and Mongolia, it is necessary to assume the role of a supplier of agricultural products, forestry complex and mineral raw materials. To maintain competitiveness, this function must be fulfilled, receiving maximum added value and preserving the biosphere as the main source of added value in the emerging division of labor. In this regard, the cooperation of Mongolia and Russia in the field of research and development, including, and possibly in a priority order, for the AIC of the economies of our countries, seems promising.

Currently, the innovative systems of Russia and Mongolia are in the process of formation and development, construction of innovative infrastructure. The task is to ensure the formation of their innovative economies and promote the participation of Russia and Mongolia as equal partners in the global innovation process.

Mongolia and Russia have a mutual interest in the further development of trade and economic relations, hence the need for a joint approach to solving strategic development problems within the framework of the transition to an innovative type of development in a strategic perspective, including through the creation of highly efficient centers for the transfer of Russian high technologies to agricultural sector. This could dramatically activate the innovative, high-tech aspect of the interaction between Russia and Mongolia in the field of development of innovatively active agricultural small and medium-sized businesses and agribusiness as a whole, cross-border regional innovative cooperation and trade in environmentally friendly Mongolian agricultural products in Russia and the attraction of Russian investments in Mongolia. Mongolia is extremely interested in the latter, as well as in the import of high Russian technologies, Russian medium and heavy equipment, for which, in particular, the Altanbulag free trade zone was established, adjacent to the Russian border in the region of Kyakhta (Republic of Buryatia) [2]. This will make it possible to obtain a synergistic effect from Russian-Mongolian cooperation, which may result not only in the acceleration of the formation of the innovation system infrastructure of Mongolia, but also in the consolidation of the innovative potentials of our countries, which can transform in the future in the creation of a unified Russian-Mongolian innovation system.

\section{Materials and Methods}

In the scientific literature on the subject and scope of the AIC, four types of innovations are distinguished: selection-genetic; technical and technological and industrial; organizational and managerial and economic and socio-environmental [3]. Their use allows us to most effectively solve the problems of agricultural production in Russia and in Mongolia, including in the framework of Russian-Mongolian cooperation in the innovative field of agricultural production [4]. So, increasing soil fertility is solved by introducing appropriate production and technical and technological innovations into agricultural production. Biological processes in agriculture are improved through breeding and genetic innovations in combination with production ones. The specific nature of the climatic conditions determines the requirements for the creation of zoned varieties of crops, livestock breeds. Seasonal production in agriculture also necessitates high technical equipment - it requires the creation of appropriate systems of agricultural universal machines and technologies that could be used in various agricultural and other related activities that increase the efficiency of agricultural production, for example, laying highways, housing, organization of non-waste production, etc.

The above indicates the urgency of innovative developments for agriculture and the importance of their timely implementation in the AIC as a whole as one of the conditions for the effective functioning of business entities in Russia and Mongolia. Implementation of innovative developments for agriculture can be, for example, based on methods: 1) 
radiation processing of food products for: a) increasing the duration of their storage without destroying vitamins, impairing the appearance and nutritional and taste qualities of food products; b) reduce energy and labor costs for maintaining low temperature and drying food; c) elimination of the harmful effects of preservatives used in food; d) prevention of seed germination during storage; e) the destruction of insects and the reduction of seeding by microorganisms [5];2) the biological utilization of various organic waste while producing effective fertilizer and highly nutritious feed;3) management of agricultural operations in agricultural enterprises based on resource-saving geoinformation technologies; 4) water-saving operational regime of irrigation, etc. These methods are described in detail in [4-8]. Let us analyze the main technological innovations in the agroindustrial complex based on these methods.

\section{Results and Discussion}

Although agriculture in Mongolia began to develop only in the late 1950s, by 1985 it already produced more than $30 \%$ of all agricultural products. and provided the population of Mongolia with agricultural products completely until the 1990s. However, the intensive growth rate of agricultural production could not but affect the agroecological situation in Mongolia, which until 2000 was considered quite favorable. Currently, land and water sources are being polluted in Mongolia, and pasture land is being reduced or extinct. Given the negative aspects of the agro-climatic conditions of Mongolia, which are negative for agriculture and cattle breeding, such as drought, the presence of significant desert (Gobi) and semi-desert areas, the presence of soil salinity and land depletion, agricultural production, including livestock breeding, becomes unprofitable in some areas.

As a result, grain production by 1999 decreased by more than 3 times [6]. To rectify the situation, the Mongolian government developed and began implementing the programs "Revival of agricultural production" (Celina III) and "Green Revolution". The main directions of improving the efficiency of agriculture are: 1) the formation of regulatory and legislative support for the strategic development of the industry and the human resources of agriculture, taking into account the requirements of an innovative economy; 2) the modernization of production assets in accordance with the requirements of advanced resource-saving technologies; 3) development of a production management system, including the use of information and communication technologies. A course was taken towards the development of cattle breeding (especially in rural areas) with a focus on deeper processing of livestock raw materials and the creation of joint agricultural enterprises.

In accordance with the National Innovation Plan, the implementation of the strategy for the development of innovative activity in Mongolia is supposed to be in two stages in the period 2016-2025 and focuses, among other things, on improving the infrastructure of agriculture and export sectors, stimulating the introduction of innovations and the production of high-tech products. The main areas of the Mongolian economy with a high level of innovation are export-oriented agricultural and mining infrastructure, production of environmentally friendly products from agricultural and mineral raw materials, and chemical production. Mongolian enterprises operating in these areas of the Mongolian economy have the opportunity to receive state subsidies for the acquisition of the latest technology and marketing research.

The Mongolia Innovation Index (Fig. 1), calculated by Cornell University and the European Institute of Business Management (INSEAD) based on data provided by the World Intellectual Property Organization (WIPO), covers the elements of the national economy that provide innovation: 1) institutions, 2) human capital and research, 3) 
infrastructure, 4) market conditions, 5) the complexity of doing business, 6) knowledge and technology, 7) creative results [10].

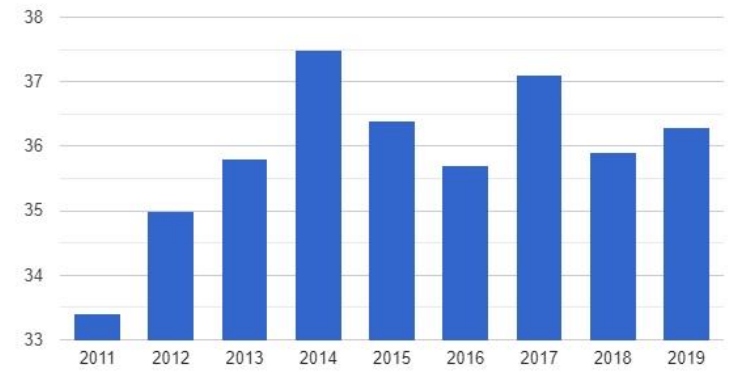

Fig. 1. Mongolia Innovation Index on a scale of 0-100 points

With the adoption of the Law "On Innovation" of 05.22.2012, which enshrines the national innovation strategy, the development of innovation in Mongolia is relatively stable (indicators within 33.4 (in 2011) - 37.5 points (in 2014), the average value in Mongolia for this period amounted to 35.9 points), and the growth trend was associated with the adoption of the national innovation plan and its implementation. Further decline in indicators in 2015-2019 shows that Mongolia does not sufficiently use innovative achievements in the economy, including due to the reduction in this period of world prices for mineral (the main export of Mongolia) and agricultural raw materials.

The development of resource-saving technologies in agriculture is one of the most important directions for bringing production to a qualitatively new level, which provides the opportunity for agricultural producers to produce competitive products. In this direction, Russian scientists can propose: 1) management systems: a) agrotechnological operations in agricultural enterprises based on resource-saving geoinformation technologies [8] and b) water-saving operational irrigation regime; 2) technology: a) determining the water resistance of the non-pressure groundwater horizon for the purpose of designing mine and small-tube wells; b) water reclamation [4].

As part of the organization of non-waste agricultural production, highly effective innovative technologies can be proposed for accelerating the natural processes of decomposition of organic (not only biological but also, for example, polymer household) waste and the production of highly nutritious feed and effective fertilizer for composting the soil, which improves its fertility and allows enrichment of it with useful elements.

Another important area of Russian-Mongolian cooperation may be the ecological and geochemical assessment of land in the framework of monitoring and studying the degradation stability of natural and man-made landscapes based on Russian innovative technologies. For Mongolia, the development of Russian scientists in the field of veterinary medicine and zoo engineering in the field of raising highly productive cows with the introduction of a breeding and control farm (dairy cows with optimal live weight and programmed milk production for the first lactation $(4000-4600 \mathrm{~kg}$ of milk) can be relevant for Mongolia; comprehensive programs for the production of feed and the organization of full-fledged feeding of farm animals; breeding and technological systems to increase longterm productivity full use of dairy cows, as well as technologies for keeping, feeding and raising cows in personal farmsteads and farms [4].

The actual direction of innovative development, which allows to increase the economic efficiency and environmental friendliness of agricultural activity, is the development of minerals. In Mongolia and Russia, as a rule, it leads to the destruction of the fertile layer of soil for agricultural production and to further long-term and irreversible erosion of the surrounding landscape, including at the end of mining. The use of innovative technologies 
ensures the restoration of the fertile layer at the end of their extraction and eliminates its further erosion.

At present, the task of preserving the Russian "pearl" of world significance - Lake Baikal is extremely urgent for Russia. In particular, the federal target program "Protection of Lake Baikal and the Socio-Economic Development of the Baikal Natural Territory for 2012-2020" provides for subsidies from the federal budget to the budgets of the constituent entities of the Russian Federation for environmental protection measures for the disposal and processing of accumulated industrial waste and alternative socio-economic development of the Baikal region and is aimed at reducing the discharge of pollutants into its water bodies, reducing the level of pollution by waste, etc. [11].

However, the importance of solving this problem goes far beyond the implementation of Russian projects: it cannot be effectively solved without the environmental assistance of Mongolia. The range of measures implemented by Russia cannot be complete without increasing the environmental friendliness of the activities of agricultural enterprises, primarily through the introduction of non-waste innovative technologies, in the Selenga river basin. The agro-industrial complex of Mongolia and the corresponding Russian territory has the greatest responsibility and the greatest environmental burden associated with maintaining the unique ecological system of Lake Baikal, which determines the need to maintain a special nature management regime and use special management regimes, including more advanced cleaning facilities, the introduction of recycled water supply systems, reconstruction and modernization of agricultural production, development and implementation of environmentally friendly technology, higher requirements for accommodation and functioning of productive forces in agriculture. All this can be realized only with the transition of the agro-industrial complex of Mongolia and the corresponding Russian territory to an innovative type of development. It is innovative technologies that make it possible to ensure non-waste recycling of agricultural waste and agro-industry as a whole.

In Mongolia, the problem of salinization of water in reservoirs and wells used both for livestock watering and for human needs is urgent, which requires the use of easily transported and installed equipment using desalination technologies based on primarily the most affordable and cheapest source - solar energy (in Mongolia, an average of 330 days a year is clear weather) [6]. Covering greenhouses can transform solar energy into electricity, used not only for lighting and heating the greenhouse at night and during cold periods, but also to provide electricity for the infrastructure adjacent to the greenhouse, for example, residential and social facilities.

Currently, the global trend is the transition from the use of disposable tableware made of polymeric materials to disposable tableware made of quickly decomposable harmless, even edible, materials. As a raw material for such utensils, husks from seeds, buckwheat, rice, grains, legumes, shells from processing hazelnuts, straw, chaff and other wastes of the corresponding crops, which are currently usually not only irretrievably lost but can also lead to environmental pollution, intensive reproduction of insects and rodents, fires, can be used..

In Russia there are all of the listed innovative technologies.

\section{Conclusions}

1. The implementation of a package of innovatively oriented measures in the AIC of Mongolia will require, based on relevant studies, the development potential of the Mongolian agro-industrial complex and the existing experience in introducing highly effective innovative developments in adopting a number of strategic program documents, including the development of economic development concepts, organizational models and 
agriculture management systems, and rational distribution models and the use of limited resources of multidisciplinary agricultural enterprises, including those which are in a state of depression or lack of economic growth. With a mutual desire to increase the effectiveness of cooperation in science, innovation and in the field of education, the availability of these documents, and the establishment of centers: a) nuclear science to implement the method of radiation processing of food; b) the transfer of Russian high technologies in the agricultural sector, for example, at Mongolian universities and branches of Russian universities in Mongolia of the appropriate profile, will ensure a synergistic effect due to targeted integrated innovative development and increase the efficiency of the functioning of agricultural production and agricultural processing industries in Mongolia, mutual accelerating economic growth of agricultural production and agribusiness of Russia and Mongolia as a whole. The result of such cooperation may be the acceleration of the formation of the infrastructure of the innovation system of Mongolia, the consolidation of the innovative potentials of our countries, which can transform in the future into the creation of a unified Russian-Mongolian innovation system.

2. Although cross-border cooperation between Russia and Mongolia in the field of agriculture is traditional, occupies a special place and develops on the basis of intergovernmental agreements and programs, a qualitative change in this area is possible by moving to the integrated development of an innovative type of border regions of Mongolia and Russia based on bilateral long-term targeted economic programs. In their implementation, it is advisable, to attract international investment to use such effective forms of cooperation as the creation of joint agricultural enterprises, centers for crossborder trade in agricultural products and agricultural products in general, agricultural clusters, free economic zones, implementation at the Russian-Mongolian border at checkpoints joint transport infrastructure projects as a key factor in the sustainable development of Russian and Mongolian border regions, including a network of modern logistics and trans-modal terminals and international transport and logistics centers, providing innovative technology, in particular for the storage and transportation of agricultural raw materials and products.

3. The relevance of preserving Lake Baikal goes far beyond the tasks of forming the economic mega-region of East Asia. The main share of responsibility for solving this problem lies with Russia. However, this task cannot be solved without the active participation of Mongolia. The task of preserving Lake Baikal requires innovative technical, organizational, managerial and economic and ecological solutions, not only for activities aimed at directly preserving the ecology of the lake, but also for organizing economic activities in the river basins supplying Lake Baikal, including in Mongolia.

\section{References}

1. A.J. Yakushev, S.A. Filin, B. Damdindorj, In the collection: Transport systems: Development trends, B.A. Levin (general ed.) (Russian University of Transport (MIIT), Moscow, 2016)

2. V.A. Babushkin, B. Damdindorzh, O.V. Rykalina, S.A. Filin Trade and economic relations between Russia and Mongolia (XIII-XXI centuries) (Crystal Press COO, Ulaanbaatar, 2016)

3. V.A. Ivanov, Corporate governance and innovative development of the economy of the North, 4 (2007)

4. T.M. Gerashchenkova, News of St. Petersburg State Agrarian University, 29 (2012) 
5. Technologies of radiation treatment in agriculture and food industry. URL: https://studbooks.net/1420777/tovarovedenie/tehnologii_radiatsionnoy_obrabotki_sels kom_hozyaystve_pischevoy_promyshlennosti

6. Z.I. Ashurli, M.G. Gajiev, E.A. Narusbek, S.A. Filin, patent for the invention RU 2044692 (1995).

7. N.M. Belous, V.E. Torikov, Catalogue of scientific developments for implementation and innovation activity (Publishing House of Bryanskaya GSHA, Bryansk, 2013).

8. T.M. Gerashchenkova, S.A. Filin, World Affairs. School of foreign service national university of Mongolia, 2/29 (415) (2014)

9. M. Damchigjavyn Problems of development of the agricultural sector of Mongolia 's economy. URL: http://vasilievaa.narod.ru/4_1_01.htm

10. Mongolia Economic Indicators. URL: https://www.theglobaleconomy.com/Mongolia/

11. For the protection of Baikal will be allocated about 1 billion rubles. Rosbalt. 27.11.2012. URL: http://news.mail.ru/economics/11091138/ 